\title{
Tip 2 Diabetes Mellituslu Hastaların Bitkisel Destek Kullanım Durumları
}

\section{Herbal Supplement Use among Patients with Type 2 Diabetes Mellitus}

\author{
Ezgi BELLİKCİ-KOYU, Banu ŞARER YÜREKLİ, Nilüfer ÖZDEMIR, Zehra BÜYÜKTUNCER
}

\footnotetext{
1 İzmir Katip Çelebi Üniversitesi Sağlık Bilimleri Fakültesi, Beslenme ve Diyetetik Bölümü, İzmir, Türkiye

2 Ege Üniversitesi Tıp Fakültesi, Endokrinoloji Bilim Dal, İzmir, Türkiye

${ }^{3}$ Hacettepe Üniversitesi Sağlık Bilimleri Fakültesi, Beslenme ve Diyetetik Bölümü, Ankara, Türkiye
}

Yazışma Adresi

Correspondence Address

\section{Ezgi BELLIKCİ-KOYU}

İzmir Katip Çelebi Üniversitesi Sağlık Bilimleri Fakültesi, Beslenme ve Diyetetik Bölümü İzmir, Türkiye

ezgi_bellikci@hotmail.com

Geliş tarihi / Received : Tem 02, 2020 Kabul tarihi / Accepted :Eyl 30, 2020

Elektronik yayın tarihi : Eyl 01, 2021 Online published

Bu makalede yapılacak atıf:

Cite this article as:

Bellikci Koyu E, Șarer Yürekli B,

Özdemir N, Büyüktuncer Z.

Tip 2 Diabetes Mellituslu

Hastaların Bitkisel Destek

Kullanım Durumlar

Akd Tip D / 2021; 7(3):377-384

Ezgi BELLIKKCI-KOYU

ORCID ID: 0000-0001-5279-2394

Banu ŞARER YÜREKLI

ORCID ID: 0000-0003-1809-2655

Nilüfer ÖZDEMIR

ORCID ID: 0000-0002-0719-988X

Zehra BÜYÜKTUNCER

ORCID ID: 0000-0002-2039-8568

\section{ÖZ}

Amaç:

Kronik seyri ve hastalığın yönetimindeki zorluklar nedeniyle tip 2 diyabetli bireyler tamamlayıcı ve alternatif tedavi yöntemlerine sıklıkla başvurabilmektedir. Bu çalışmada, Tip 2 diyabetli bireylerde bitkisel destek kullanım sıklığı ve bitkisel destek kullanımı ile ilişkili etmenlerin ortaya konulması amaçlanmıştır.

\section{Yöntem}

Tanımlayıcı tipte planlanan araştırmaya, tip 2 diyabet tanısı almış toplam 193 yetişkin birey dahil edilmiştir. Veriler, yapılandırılmış bir anket kullanılarak yüz yüze görüşme yöntemi ile toplanmıştır. Görüşmede, bireylerin genel özellikleri, sağlık durumları, bitkisel destek kullanım durumları, kullandıkları ürünler, ürünleri hazırlama yöntemleri, kullanım sıklıkları, kullanım süreleri ve ürünü tavsiye eden kişiler sorgulanmıştır. Katılımcıların antropometrik ölçümleri araştırmacılar tarafından ölçülüp kaydedilmiştir.

\section{Bulgular}

Çalışmaya katılan yaklaşık her üç kişiden birinin $(\% 30,1)$ diyabetin yönetimi için bitkisel desteklere başvurduğu belirlenmiştir. Bitkisel destek kullanan bireylerin sırasıyla \%25,9 ve \%24,1'i tarafından kullanıldığı beyan edilen tarçın ve karışım ürünler en çok tercih edilen ürünler olmuştur. Ürünlerin temin edildiği yerlerin başında aktarlar $(\% 50,7)$ gelmektedir. Bireylerin önemli bir kısmı kullandıkları bitkisel desteğe ilişkin araştırma yapmadığını $(\% 82,8)$ ve kullandıkları ürün hakkında doktorlarına bilgi vermediğini $(\% 81,0)$ bildirmiştir. Bitkisel destek kullanan bireylerin \%67,3'ünün ürünleri komșu ya da tanıdık tavsiyesi üzerine kullanmaya başladığı kaydedilmiştir. Hem bitkisel destek kullanan $(\% 79,3)$ hem de kullanmayanların $(\% 67,4)$ büyük çoğunluğu bitkisel ürünlere yönelik sağlık çalışanlarından bilgi almak istediklerini bildirmişlerdir.

\section{Sonuç}

$\mathrm{Bu}$ çalışmada diyabetli bireyler arasında bitkisel destek kullanımının yaygın olduğu ortaya konmuştur. Ürünlerin bilinçsiz kullanımını önlemek için sağlık çalışanlarının konuya ilişkin farkındalığının yüksek olmasının gerekli olduğu düşünülmektedir.

Anahtar sözcükler: Bitkisel destekler, Bitkisel ürün, Tamamlayıcı ve alternatif tedavi, Tip 2 diyabet 
Abstract

\section{Objective:}

Due to its chronic course and the difficulties in the management of disease, individuals with type 2 diabetes may frequently use complementary and alternative therapies. The aim of this study was to investigate the frequency of herbal supplement use and factors associated with it in individuals with type 2 diabetes.

\section{Method:}

A total of 193 adults diagnosed with type 2 diabetes was included in this descriptive study. Data were collected with face to face interview method using a structured questionnaire. In the interview, general characteristics of the individuals, their health status, use of herbal supplements, products they used, preparation methods of the products, frequency and duration of use and the people who recommend the product were questioned. Anthropometric measurements of the participants were measured by the researchers.

\section{Results:}

It was detected that approximately one third of people $(30.1 \%)$ participating in this study used herbal supplements in diabetes management. Cinnamon and mixed products, used respectively by $25.9 \%$ and $24.1 \%$ of herbal supplement users, were the most preferred products. The products were usually purchased from herbalists $(50.7 \%)$. Majority of the individuals reported that they did not make a research for the product $(82.8 \%)$ and did not give information to their doctors about the product they use $(81.0 \%)$. Among $67.3 \%$ of the herbal supplement user indicated that they started to use the products with the recommendation of neighbors or acquaintances. Both the majority of the herbal product users $(79.3 \%)$ and non-users $(67.4 \%)$ stated that they want to get information from healthcare professionals for herbal products.

\section{Conclusion:}

This study revealed that the use of herbal supplements is common among individuals with type 2 diabetes. It is considered that health professionals should be aware of the issue in order to prevent misuse of the products.

Keywords: Herbal supplements, Herbal product, Complementary and alternative medicine, Type 2 diabetes

\section{GIRIŞ}

Yaşadığımız yüzyılın en önemli sorunlarından biri olan tip 2 diyabet, hem gelişmekte olan hem de gelişmiş ülkelerdeki en önemli morbidite ve mortalite sebepleri arasında yer almaktadır. Uluslararası Diyabet Federasyonu'nun (IDF) 2019 yılı tahminlerine göre Dünya'da 463 milyon diyabetli birey bulunmaktadır ve 2045 yılı tahminleri bu sayının 700 milyona ulaşacağını göstermektedir (1). Ülkemiz için yapılan tahminler ise 2045 yılında diyabetli birey sayısının 10,4 milyona ulaşacağı ve Dünya'da diyabetin en yaygın olduğu 10. ülke olacağımız yönündedir (1).
Dünya'daki diyabetli bireylerin yaklaşık \%90'ını tip 2 diyabetli bireyler oluşturmaktadır (1). Tip 2 diyabetin tedavisinde oral anti-diyabetikler ve gerekli durumda insülin kullanılmakla birlikte, hastalığın yönetiminde beslenme ve fiziksel aktiviteyi içeren yaşam tarzı alışkanlıkları kritik öneme sahiptir (2). Hastalığın yönetimindeki zorluklar ve hastalığın kronik seyirli olması diyabetli bireylerin tamamlayıcı ve alternatif tedavi yöntemlerine karşı ilgi duymasını sağlayabilmektedir (3). Diyabetli bireylerde tamamlayıcı ve alternatif tedavi kullanımının yaygın olduğu ve bu yöntemlere başvurma sıklığının \%17 ile \%72,8 arasında değiştiği bildirilmiştir (4). Çalışmalar, bu yöntemler arasında diyabetli bireyler tarafindan en sik tıbbi bitkilerin tercih edildiğini göstermektedir (4-6).

Tıbbi bitkiler bileşimlerindeki sekonder metabolitler ile birçok hastalığın tedavisinde ilaç ham maddesi olarak kullanılmaktadır. Bugün diyabet tedavisinde en sık kullanılan oral antidiyabetik ajanlardan biri olan metforminin Galega officinalis bitkisinden köken aldığı bilinmektedir (7). Bu bitkideki önemli bir kimyasal bileșen olan guanidinin, anti-diyabetik etki gösterdiği ancak toksisitesi yüzünden klinikte kullanıma uygun olmadığı belirlenmiştir. Sonraki dönemlerde toksisite riski düşük guanidin türevlerinin sentezlenmesine yönelik çalışmalar sürdürülmüş ve 1957 yılında metforminin diyabet tedavisinde kullanılabileceği ortaya konmuştur (8).

Bitkiler potansiyel ilaç hammaddesi olmalarına karşın, dikkatsiz kullanılmaları durumunda çeşitli ilaç etkileşimlerine ve toksisitelere neden olmaktadır (9). Bununla birlikte, halk arasındaki zararsız olduklarına yönelik genel inanç, medyada yer alan haberler ya da reklamlar ürünlerin kontrolsüz kullanımlarını teşvik edebilmektedir (10). Bireylerin sıklıkla kulland1kları bitkileri incelemek, bu bitkilerin potansiyel etkinlik ve güvenilirliklerini takip edebilmek ve değerlendirebilmek açısından önemlidir. Bu nedenle, bu çalışmada tip 2 diyabetli bireylerde bitkisel destek kullanım durumunun ve bitkisel destek kullanımı ile ilişkili etmenlerin ortaya konulması hedeflenmiştir.

\section{GEREÇ ve YÖNTEM \\ Çalışma Tasarımı}

Tanımlayıcı ve kesitsel tipte planlanan bu araştırma, Haziran 2015-Aralık 2016 tarihleri arasında Ege Üniversitesi Tıp Fakültesi Endokrinoloji Polikliniği’nde yürütülmüştür. Çalışmaya, 18 yaş üstü tip 2 diyabet tanısı almış toplam 193 kişi dahil edilmiştir.

\section{Veri Toplama Araçları}

Araştırma yüz yüze görüşme yöntemiyle önceden yapılandırılmış bir veri toplama formu kullanılarak gerçekleştirilmiştir. Veri toplama formu literatürdeki önceki çalışmalar incelenerek oluşturulmuş ve formun anlaşılırlığını ölçmek için önce 15 bireyle ön deneme yapılmıștır. Ön denemenin ardından gerekli düzeltmeler yapılmış ve araştırmaya başlanmıştır. Araştırmada kullanılan veri toplama formu iki bölümden oluşmaktadır. İlk bölümde sosyo-demografik 
Tip 2 Diabetes Mellituslu Hastaların Bitkisel Destek Kullanım Durumları

özelliklere ve tıbbi öykülere ilişkin bilgiler, ikinci bölümde ise katılımcıların bitkisel desteklere yönelik düşünceleri ve diyabet tedavisi için bitkisel destek kullanma durumları sorgulanmıştır. Bitkisel destek kullandığını belirten bireylere, kullandıkları ürünler, hazırlama yöntemleri, kullanım sıklıkları, kullanım süreleri ve ürünü tavsiye eden kişiler gibi çeşitli sorular yönetilmiştir. Bireylerin birden fazla bitkisel destek kullanması durumunda, bu bilgiler kullanılan her bir ürün için ayrı ayrı sorgulanmıştır. Bitkisel ürünlere yönelik sorulan sorular Tablo I.'de sunulmuştur. Katılımcıların antropometrik ölçümleri araştırmacılar tarafından ölçülüp kaydedilmiştir. Vücut ağırlığının ölçülmesinde Tanita 418 marka vücut analiz cihazı, boy uzunluğunun ölçülmesinde ise $0,1 \mathrm{~cm}$ hassasiyetindeki stadiometre (Nan Tartı A.Ş) kullanılmıştır. Beden kütle indeksi (BKI), vücut ağırlığının (kg) boy uzunluğunun (m) karesine bölünmesi ile hesaplanmıştır (11).

Tablo I Bitkisel Ürünlere Yönelik Sorulan Sorular

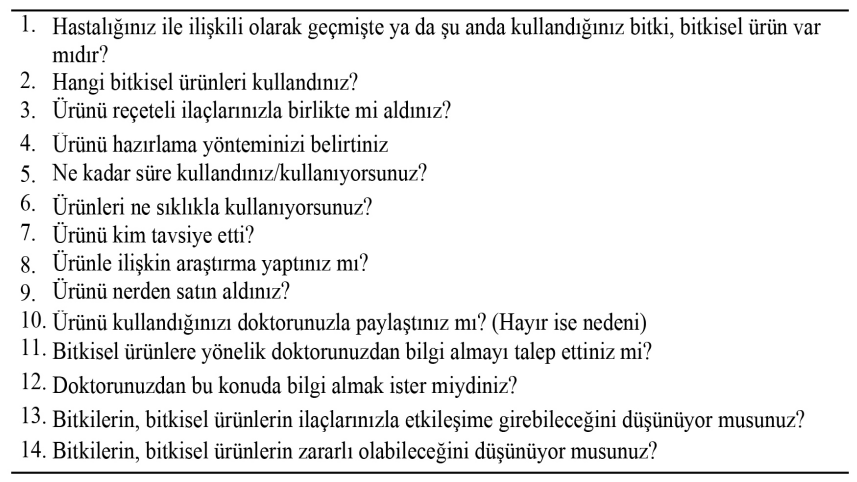

\section{Etik İzinler}

Araştırmanın yürütülebilmesi için gerekli izinler, Hacettepe Üniversitesi Girişimsel Olmayan Klinik Araştırmalar Etik Kurulu'ndan, 13.05.2015 tarih ve GO-15/334-20 karar numarası ile alınmıştır. Katılımcılara önce araştırma hakkında sözlü bilgi verilmiş, bireyler araştırmaya katılmaya gönüllü olmaları ve yazılı onam formunu imzalamaları halinde çalışmaya dahil edilmiştir. Araştırma Helsinki Bildirgesine uygun olarak yürütülmüş olup, araştırma ve yayın etiğine uyulmuştur.

\section{İstatiksel Analiz}

İstatistiksel analizler Statistical Package for Social Sciences (SPSS) versiyon 21 programı ile yapılmıştır. Tanımlayıcı bulgular, sürekli sayısal veriler için ortalama ve standart sapma, kategorik veriler için ise sayı ve yüzde olarak verilmiştir. Bitkisel destek kullanan ve kullanmayan bireylerin özelliklerinin karşılaştırılmasında, nitel veriler için ki kare testi ve gerekli durumlarda Fisher's exact test kullanılmıştır. Sürekli sayısal verilerin normal dağılıma uygunluğu Sha- piro Wilk testi ile belirlenmiştir. Veriler normal dağılıma uymadı̆̆ için analizler Mann-Whitney U testi kullanılarak gerçekleştirilmiştir. Tüm sonuçlar için anlamlılık düzeyi $\mathrm{p}<0,05$ olarak alınmıştır.

\section{BULGULAR}

Çalışmaya katılan bireylerin yaş ortalaması $56,86 \pm 10,14$ yıl olup; katılımcıların \%65,3'ü kadın, \%34,7'si erkektir. Çalışmaya katılan bireylerin $\% 30,1^{\prime} i(n=58)$ diyabetin yönetiminde bitkisel desteklere başvurduğunu bildirmiştir. Bitkisel destek kullananların \%59,9'u şu anda, \%43,1'i ise daha önceki dönemde bitkisel destek kullandığını ifade etmiştir. Bitkisel destek kullanan ve kullanmayan bireylerin cinsiyet, medeni durum, eğitim durumu ve meslek gibi sosyo-demografik özellikleri, diyet uygulama durumları, oral antidiyabetik veya insülin kullanma durumları arasında fark olmadığı belirlenmiştir (her biri için p>0,05) (Tablo II).

Tablo II Diyabetin Tedavisi İçin Bitkisel Destek Kullanan ve Kullanmayan Bireylerin Demografik Özelliklerinin ve Sağlık Durumlarının Karşılaştırılması

\begin{tabular}{|c|c|c|c|c|}
\hline & Toplam & $\begin{array}{l}\text { Bitkisel Destek } \\
\text { Kullanan } \\
(\mathrm{n}=58)\end{array}$ & $\begin{array}{l}\text { Bitkisel } \\
\text { Destek } \\
\text { Kullanmayan } \\
(\mathrm{n}=135)\end{array}$ & $\mathrm{p}^{*}$ \\
\hline Yaş (yll) & $56,86 \pm 10,14$ & $57,74 \pm 9,58$ & $56,48 \pm 10,38$ & 0,568 \\
\hline Cinsiyet & & & & 0,965 \\
\hline Kadın & $126(\% 65,3)$ & $38(\% 65,5)$ & $88(\% 65,2)$ & \\
\hline Erkek & $67(\% 34,7)$ & $20(\% 34,5)$ & $47(\% 34,8)$ & \\
\hline Medeni Durum & & & & 0,282 \\
\hline Evli & $165(\% 85,5)$ & $52(\% 89,7)$ & $113(\% 83,7)$ & \\
\hline Bekar & $28(\% 14,5)$ & $6(\% 10,3)$ & $22(\% 16,3)$ & \\
\hline Eğitim Durumu & & & & 0,456 \\
\hline İlkokul ve altı & $87(\% 45,1)$ & $30(\% 51,7)$ & $57(\% 42,2)$ & \\
\hline Ortaokul & $22(\% 11,4)$ & $4(\% 6,9)$ & $18(\% 13,3)$ & \\
\hline Lise & $35(\% 18,1)$ & $11(\% 19,0)$ & $24(\% 17,8)$ & \\
\hline Üniversite ve üzeri & $49(\% 25,4)$ & $13(\% 22,4)$ & $36(\% 26,7)$ & \\
\hline Meslek & & & & 0,654 \\
\hline Ev hanımı & $74(\% 38,3)$ & $20(\% 34,5)$ & $54(\% 40,0)$ & \\
\hline Serbest meslek & $6(\% 3,1)$ & $1(\% 1,7)$ & $5(\% 3,7)$ & \\
\hline Memur & $16(\% 8,3)$ & $3(\% 5,2)$ & $13(\% 9,6)$ & \\
\hline Emekli & $80(\% 41,5)$ & $29(\% 50,0)$ & $51(\% 37,8)$ & \\
\hline İșçi & $14(\% 7,3)$ & $4(\% 6,9)$ & $10(\% 7,4)$ & \\
\hline Diğer & $3(\% 1,6)$ & $1(\% 1,7)$ & $2(\% 1,5)$ & \\
\hline Diyet Uygulama Durumu & & & & 0,885 \\
\hline Evet & $85(\% 56,0)$ & $26(\% 44,8)$ & $59(\% 43,7)$ & \\
\hline Hayır & $108(\% 44,0)$ & $32(\% 55,2)$ & $76(\% 56,3)$ & \\
\hline Oral Antidiyabetik Kullanımı & & & & 0,972 \\
\hline Evet & $160(\% 82,9)$ & $48(\% 82,8)$ & $112(\% 83,0)$ & \\
\hline Hayır & $33(\% 17,1)$ & $10(\% 17,2)$ & $23(\% 17,0)$ & \\
\hline İnsulin Kullanımı & & & & 0,156 \\
\hline Evet & $47(\% 24,4)$ & $18(\% 31,0)$ & $29(\% 21,5)$ & \\
\hline Hayır & $146(\% 75,6)$ & $40(\% 69,0)$ & $106(\% 78,5)$ & \\
\hline BKI $\left(\mathrm{kg} / \mathrm{m}^{2}\right)$ & $32,38 \pm 6,53$ & $30,98 \pm 5,56$ & $32,98 \pm 6,84$ & 0,053 \\
\hline
\end{tabular}

* Kategorik veriler ki-kare analizi, sürekli veriler Mann-Whitney U Testi ile hesaplanmıştır.

Bitkisel destek kullanan bireylerin BKİ ortalamaları $(30,98 \pm 5,56 \mathrm{~kg} / \mathrm{m} 2)$, bitkisel destek kullanmayanlara $(32,98 \pm 6,84 \mathrm{~kg} / \mathrm{m} 2)$ göre daha düşük olmakla birlikte bu durum istatistiksel açıdan anlamlı bulunmamıştır ( $p=0,053)$. Diyabetli bireyler tarafindan kullanılan bitkisel destekler Tablo III'te verilmiştir. Buna göre, diyabet tedavisinde toplam 18 farklı bitkisel ürünün tercih edildiği belirlenmiştir. Bitkisel destek kullanan bireylerin \%25,9'u tarafindan tercih edilen tarçın ve \%24,1'i tarafından tercih edilen karışımlar en çok kullanılan ürünlerdir. Çörek otu $(\% 13,8)$, kekik $(\% 13,8)$ ve zeytin yaprağ $\mathrm{da}(\% 12,1)$ en sık tercih edilen bitkiler arasındadir. 
Tablo III Diyabetli Bireyler Tarafından Kullanılan Bitkiler

\begin{tabular}{lcc}
\hline Kullanılan Bitkiler & Sayı & Yüzde* \\
\hline Tarçın & 15 & 25,9 \\
Karışımlar & 14 & 24,1 \\
Çörek otu & 8 & 13,8 \\
Kekik & 8 & 13,8 \\
Zeytin yaprağı & 7 & 12,1 \\
Enginar & 2 & 3,4 \\
Kudret narı & 2 & 3,4 \\
Karabaş otu & 1 & 1,7 \\
Isırgan otu & 1 & 1,7 \\
Limon & 1 & 1,7 \\
Biberiye & 1 & 1,7 \\
Kaynana dili & 1 & 1,7 \\
Meșe palamudu & 1 & 1,7 \\
Çınar yaprağı & 1 & 1,7 \\
Lahana & 1 & 1,7 \\
Nar & 1 & 1,7 \\
Pelin otu & 1 & 1,7 \\
Çakal eriği & 1 & 1,7 \\
\hline
\end{tabular}

*Birden fazla ürün kullanan birey mevcuttur.

Diyabetin yönetimi için bitkileri karışım olarak kullanan bireylere, kullandıkları karışımların içerisindeki bitkiler de sorulmuş ve bunların listesi Tablo IV'te sunulmuştur. Buna göre, yedi karışımın bileşiminde bulunarak karışımların içerisinde de en fazla yer alan bitkinin tarçın olduğu belirlenmiştir. Tarçın dışında çörek otunun dört, zencefilin üç, arpa, buğday, limon, keten tohumu, zeytin yaprağı ve zerdeçalın iki karışıma girdiği saptanmıştır.

Tablo IV Diyabetli Bireyler Tarafından Kullanılan Karışımlar

\begin{tabular}{lc}
\hline Karışım & Sayı \\
\hline Arpa-buğday-yulaf & 1 \\
Arpa-buğday-çörekotu-çam sakızı & 1 \\
Ceviz yaprağı-limon & 1 \\
Çörek otu-keten tohumu- tarçın-zencefil-zerdeçal & 1 \\
Çörek otu-keten tohumu-tarçın & 1 \\
Çörek otu-mahlep-tarçın & 1 \\
Hibiscus-kuşburnu & 1 \\
Tarçın-zencefil & 1 \\
Tarçın-zencefil-zerdeçal & 1 \\
Tarçın-zeytin yaprağı & 1 \\
Tarçın-zeytin yaprağı-limon & 1 \\
Bilmiyor & 3 \\
\hline
\end{tabular}

Bu çalışmada, bireylerin büyük çoğunluğunun $(\% 91,4)$ bitkisel destekleri ilaçları ile birlikte kullandığ saptanmıștır. Bireylerin \%60,3'ü ürünleri 0-3 ay süreyle kullanırken,1 yıldan uzun süreli kullananların oranı \%20,7'dir. Ürünler en sik infüzyon (demleme) $(\% 34,3)$ veya dekoksiyon (kaynatma) $(\% 26,8)$ yöntemi ile hazırlanmaktadır. Ürünlerin yaklaşık yarısının $(\% 49,3)$ düzenli olarak her gün; \%11,9'unun haftada 3-4 gün; \%11,9'unun haftada 1-2 gün; \% 7,5'inin ise bireylerin kan şekerlerinin yükseldiği durumlarda kullanıldığı belirlenmiştir.
Tablo V Bitkilerin Kullanımlarına Illişkin Bazı Bilgiler

\begin{tabular}{|c|c|c|}
\hline & Sayı & Yüzde \\
\hline \multicolumn{3}{|l|}{ Kullanım Șekli } \\
\hline İlaçları ile birlikte & 53 & 91,4 \\
\hline İlaçları yerine & 5 & 8,6 \\
\hline \multicolumn{3}{|l|}{ Kullanim Süresi (ay) } \\
\hline $0-3$ ay & 35 & 60,3 \\
\hline $4-6$ ay & 3 & 5,2 \\
\hline 6-12 ay & 8 & 13,8 \\
\hline$>12$ ay & 12 & 20,7 \\
\hline \multicolumn{3}{|l|}{ Hazırlama Yöntemi* } \\
\hline İnfüzyon & 23 & 34,3 \\
\hline Dekoksiyon & 18 & 26,8 \\
\hline Doğrudan tüketerek & 8 & 11,9 \\
\hline Besinlerle karıştırarak & 6 & 9,0 \\
\hline Kapsül formunda & 3 & 4,5 \\
\hline Zeytinyağı ile karıştırarak & 2 & 3,0 \\
\hline Yağ1 & 2 & 3,0 \\
\hline Diğer & 5 & 7,5 \\
\hline \multicolumn{3}{|l|}{ Kullanım Sıklı̆̆g * } \\
\hline Her gün & 33 & 49,3 \\
\hline Haftada 3-4 kez & 8 & 11,9 \\
\hline Haftada 1-2 kez & 8 & 11,9 \\
\hline Ara sıra-hatırladıkça & 12 & 17,9 \\
\hline Şekeri yükseldiği zaman & 5 & 7,5 \\
\hline Yılda birkaç kez & 1 & 1,5 \\
\hline \multicolumn{3}{|l|}{ Satın Alıan Kaynak* } \\
\hline Aktar & 34 & 50,7 \\
\hline Toplama & 16 & 23,9 \\
\hline Market/manav & 8 & 11,9 \\
\hline Pazar & 4 & 6,0 \\
\hline İnternet & 2 & 3,0 \\
\hline Diğer & 3 & 4,5 \\
\hline \multicolumn{3}{|l|}{ Araştırma Yapma Durumu } \\
\hline Evet & 10 & 17,2 \\
\hline Hayır & 48 & 82,8 \\
\hline \multicolumn{3}{|l|}{ Doktora Danışma } \\
\hline Evet & 11 & 19,0 \\
\hline Hayır & 47 & 81,0 \\
\hline \multicolumn{3}{|l|}{ Danışmama Nedeni } \\
\hline Aklına gelmediği-unuttuğu için & 13 & 27,7 \\
\hline Doktoru sormadiğ 1 için & 12 & 25,5 \\
\hline Doktora gitmediği için & 9 & 19,1 \\
\hline Gerekli olduğunu düşünmediği için & 5 & 10,6 \\
\hline Kisa süreli-düzensiz kulland 1 ğ 1 için & 4 & 8,5 \\
\hline Korktuğu-utandığ 1 için & 2 & 4,3 \\
\hline Diğer & 2 & 4,3 \\
\hline
\end{tabular}

*Yüzdeler toplam kullanılan ürün sayısına $(n=67)$ göre hesaplanmıştır.

Ürünlerin temin edildiği yerlerin başında aktarlar $(\% 50,7)$ gelmekte olup, bunu bahçeden toplama $(\% 23,9)$ ve marketten satın alma $(\% 11,9)$ izlemektedir. Bireylerin büyük bir kısmı kullandıkları bitkisel desteğe ilişkin araştırma yapmadığını $(\% 82,8)$ ve kullandıkları ürünü doktorları ile paylaşmadıklarını $\quad(\% 81,0) \quad$ bildirmiştir. Bireylerin kullandıkları ürünleri doktorları ile paylaşmamalarının nedenleri arasında unutmaları-akıllarına gelmemesi $(\% 27,7)$ ve 
doktorlarının sormaması $(\% 25,5)$ başta gelmektedir (Tablo V). Bitkisel destek kullanan bireylerin önemli bir k1smı (\%67,3) ürünleri komşu ya da tanıdık tavsiyesi üzerine kullandığını belirtmiştir. Bireylerin \%22,4’ü ise gazete ve televizyondan etkilenerek ürünü aldığını bildirmiştir. Bitkisel desteklere sağlık profesyonellerinin tavsiyesi üzerine başlayan birey bulunmamaktadır (Grafik I).

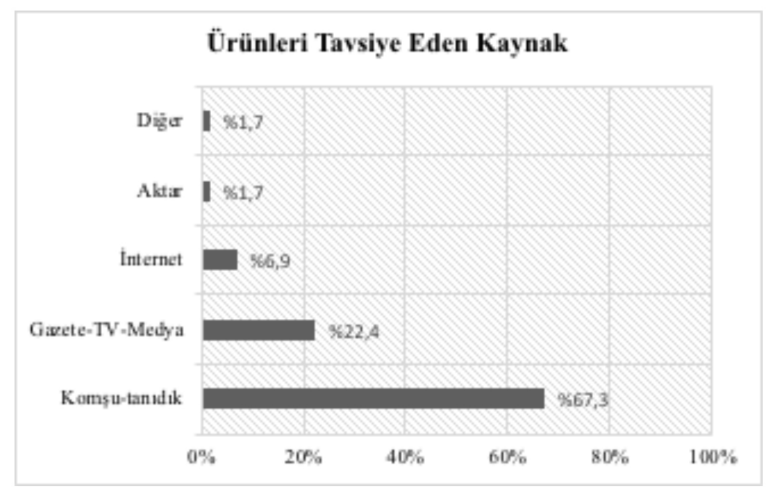

Grafik I Ürünleri Tavsiye Eden Kaynak

Çalışmaya katılan bireylerin bitkisel desteklere yönelik bazı düşünceleri Tablo VI'da sunulmuştur. Sağlık çalışanlarından bitkisel desteklere ilişkin bilgi almış olanların oranı bitkisel destek kullanan grupta kullanmayanlara göre daha yüksek bulunmuştur $(\mathrm{p}=0,008)$. Ancak, hem bitkisel destek kullanan $(\% 79,3)$ hem de kullanmayanların $(\% 67,4)$ büyük çoğunluğu sağlık çalışanlarından bu konuda bilgi almak istediğini belirtmiştir. Bireylerin yaklaşık yarısı, bitkilerin ilaçlar ile etkileşebileceğini ve bitkilerin zararlı olabileceğinin farkında olduklarını ifade etmiştir (Tablo VI).

Tablo VI Bireylerin Bitkisel Desteklere Yönelik Düşünceleri

\begin{tabular}{|c|c|c|c|}
\hline & $\begin{array}{l}\text { Bitkisel Destek } \\
\text { Kullanan } \\
(\mathrm{n}=58)\end{array}$ & $\begin{array}{l}\text { Bitkisel Destek } \\
\text { Kullanmayan } \\
(\mathrm{n}=135)\end{array}$ & $\mathbf{p}$ \\
\hline $\begin{array}{l}\text { Bitkisel desteklere ilisskin sağlık } \\
\text { çalışanlarından bilgi aldınız mı? }\end{array}$ & & & $\overline{0,008^{\mathrm{a}}}$ \\
\hline Evet & $8(\% 13,8)$ & $4(\% 3,0)$ & \\
\hline Hayır & $50(\% 86,2)$ & $131(\% 97,0)$ & \\
\hline $\begin{array}{l}\text { Bitkisel desteklere ilisskin sağlık } \\
\text { calıssanlarından bilgi almak ister } \\
\text { miydiniz? }\end{array}$ & & & 0,095 \\
\hline Evet & $46(\% 79,3)$ & $91(\% 67,4)$ & \\
\hline Hayır & $12(\% 20,7)$ & $44(\% 32,6)$ & \\
\hline $\begin{array}{l}\text { Bitkiler ilaçlarınız ile etkileșebilir mi? } \\
\text { Evet }\end{array}$ & & & 0,957 \\
\hline Hayır & $30(\% 51,7)$ & $69(\% 51,1)$ & \\
\hline Fikrim yok & $\begin{array}{l}4(\% 6,9) \\
24(\% 41,4)\end{array}$ & $\begin{array}{l}8(\% 5,9) \\
58(\% 43,0)\end{array}$ & \\
\hline Bitkiler zararlı olabilir mi? & & & 0,264 \\
\hline Evet & $33(\% 56,9)$ & $67(\% 49,6)$ & \\
\hline Hayır & $13(\% 22,4)$ & $46(\% 34,1)$ & \\
\hline Fikrim yok & $12(\% 20,7)$ & $22(\% 16,3)$ & \\
\hline
\end{tabular}

${ }^{a}$ Fisher's Exact Test kullanılmıştır. Diğer verilerin analizi için Ki-kare testi kullanılmıştır.

\section{TARTIŞMA}

$\mathrm{Bu}$ araştırmada, tip 2 diyabetli bireylerde bitkisel destek kullanımının yaygın olduğu ve yaklaşık her üç diyabetli bireyden birinin diyabetin yönetiminde bitkisel ürünlere başvurduğu belirlenmiştir. Konuya ilişkin ülkemizde yürütülen diğer çalışmalarda bu oranın \%22,0-57,6 arasında değiştiği gösterilmiştir (12-14). Diyabetik bireylerde tamamlayıcı tedavi ve bitkisel destek kullanım sıklığının ülkelere, bölgelere, kültürlere ve sağlık merkezlerine erişilebilirlik durumuna göre değişiklik gösterdiği bilinmektedir $(4,6)$. Almanya'da yürütülen bir çalışmada, farmakolojik tedaviden memnuniyetsizlik, geçmiş deneyimler ve aile geleneklerinin de bitkisel destek kullanımı ile ilişkili etmenler arasında yer aldığı belirlenmiştir (15). Bunların dışında, bitkisel ürünlerin kolay ulaşılabilir olmaları ve reçetesiz olarak kullanılabilmeleri, "bitkisel" olduğu için güvenilir olarak algılanmaları da yaygın kullanımları ile ilişkili etmenler arasında sayılabilir (16).

Ülkemizde tip 2 diyabetli bireyler ile yürütülen bir çalışmada, tamamlayıcı ve alternatif tedavi kullanımının kadınlarda ve 50-64 yaş arası bireylerde daha yaygın olduğu saptanmıştır. Aynı çalışmada, tamamlayıcı ve alternatif tedavi kullanımı sağlıklı beslenme alışkanlıkları ile de pozitif ilişkili bulunmuştur (17). Buna karşın, ülkemizdeki birçok çalışmada, diyabetik bireylerde tamamlayıcı tedavi kullanımının cinsiyet, medeni durum, eğitim düzeyi, meslek durumu veya tıbbi beslenme tedavisi uygulama durumuna göre değişmediği rapor edilmiştir $(5,6,18)$. Bu çalışmada da benzer şekilde bitkisel destek kullanımının sosyo-demografik özellikler ile ilişkili olmadığ 1 saptanmıştır. Bu bulgular hem eğitimli kesimde, hem de eğitim seviyesi düşük olan gruplarda bitkisel desteklere yönelik bilgilendirmeye ihtiyaç duyulabileceğini göstermektedir.

Diyabet tedavisinde tercih edilen bitkiler ülkelere göre değişiklik göstermekle birlikte, hem ülkemizde hem de Dünya'da diyabet yönetimi için en sık tercih edilen bitkilerden birisi tarçındır $(5,14,16,18-21)$. Tarçının diyabet üzerine olan etkisi birçok klinik çalışmada da incelenmiştir. Yakın zamanda yapılan ve 16 randomize kontrollü çalışmanın yer aldığı bir meta-analizde, tarçın kullanımının açlık kan glukozu (ağırlıklı ortalama fark -9,8 mg/dl) ve Homeostatic Model Assessment- Insulin Resistance (HOMA-IR) değerlerinde (ağırlıklı ortalama fark -0,714) azalma sağladığı ancak hemoglobin A1c (HbA1c) üzerine etki göstermediği bildirilmiştir. Meta-analize dahil edilen çalışmalarda çoğunlukla çin tarçını (Cinnamomum cassia) kullanılmıştır (22). Bununla birlikte, çin tarçınının hepatotoksik bir bileşen olan kumarin açısından zengin olması nedeniyle kullanımına dikkat edilmesi önerilmektedir (10).

$\mathrm{Bu}$ araştırmada tarçın dişında en sık kullanılan desteklerin, birden çok bitkinin yer aldığı karışımlar, çörek otu, kekik ve zeytin yaprağı olduğu saptanmıştır. Karışımların içerisinde ise en fazla yer alan bitkilerin tarçın ve çörek otu olduğu belirlenmiştir. Ülkemizde yürütülmüş diğer çalışmalarda benzer şekilde çörek otu ve zeytin yaprağının diyabetik bireyler 
tarafından sik tercih edildiği rapor edilmiştir $(5,18,23)$. Klinik çalışmalarda da 40 gün-1 yıl süreyle günlük 2-5 gram çörek otu tüketiminin açlık kan glukozu, HbA1c ve insülin direnci üzerine olumlu etkileri olduğunu rapor eden çalışmalar bulunmaktadır (24-27). Bununla birlikte literatürde, 62 yaşındaki diyabetik bir hastada 6 gün süreyle çörek otu tableti (2-2,5 g/gün) kullanımını takiben akut böbrek yetmezliği geliştiğini bildiren bir olgu raporuna rastlanmıştır (28). Ülkemizden bildirilen bu rapor dikkat çekicidir. Klinik çalışmalarda kullanılan dozun üzerinde olmadığı halde kısa süreli kullanımın ardından böbrek yetmezliğinin gelișmesi, durumun kullanılan ürünün kalitesi ve bileşimi ile ilişkili olabileceğini düşündürmüştür (29). Bu durum, kullanılacak bitkinin güvenilir olması kadar ürünün de güvenilir olmasına dikkat edilmesi gerekliliğinin altını çizmektedir.

Bu çalışmada diyabetli bireyler tarafından sık kullanılan kekik ve zeytin yaprağı için, in-vivo çalışmaların sonuçları umut vaat edici olsa da (30-32), klinik çalışmalar henüz sınırlıdır ve sonuçları çelişkilidir (33-35). Ayrıca, kekik kullanımına yönelik önemli bir diğer husus, kekik isminin ülkemizde farklı cinste ve türde bitkiler için kullanılıyor olmasıdır (36). Bu nedenle, hastaların kullandıkları kekik türüne bağlı olarak farklı etkiler görme ihtimalleri de dikkate alınmalıdır.

Ülkemizde bitkilerin temin edildiği yerlerin başında aktarlar gelmektedir (37). Bu çalışmada da, bitkilerin çoğunlukla aktardan temin edildiği ya da toplanarak tüketildiği saptanmıştır. Ürünleri eczaneden temin eden birey bulunmaması ise dikkat çekici bir bulgudur. Konuya ilişkin diyabetli bireylerle yapılan diğer çalışmalarda da benzer bulgular rapor edilmiş ve bu durumun etkinlik ve güvenilirlik açısından bir sorun olduğunun altı çizilmiştir $(12,13)$.

Bitkisel destek kullanımı ile ilişkili en önemli risklerden biri bireylerin ilaçlarını bırakmaları veya düzensiz kullanmalarıdır (38). Bu çalışmada bireylerin tamamına yakını $(\% 91,4)$ bitkileri ilaçları yerine değil ilaçları ile birlikte kullandıklarını bildirmiştir. $\mathrm{Bu}$ bulgular, bitkisel ürünlerin konvansiyonel tedavide kullanılan ilaçların zararlı olduğuna yönelik düşünce nedeniyle tercih edilmediğini, başka bir ifade ile bitkisel desteklerin alternatif değil tamamlayıcı bir tedavi olarak kullandıklarını göstermektedir. Ancak bu durum, potansiyel ilaç etkileşimleri açısından da dikkat edilmesi gerekliliğine işaret etmektedir (39). Bu çalışmaya katılan ve bitkisel destek kullanan bireylerin \%51,7'si bitkisel ürün ilaç etkileşiminden haberdar olduğunu bildirmiştir. Buna rağmen, bitkisel destek kullananların \%81,0'inin kullandıkları ürünü doktorları ile paylaşmamaları dikkat çekicidir. Öztürk ve arkadaşlarının diyabetik bireylerle yürüttükleri çalışmada da, katılımcıların \%82,3'ünün doktorlarına haber vermeksizin bitkisel ürün kullandıkları saptanmıştır (13). Bitkisel ürün kullanımına bağlı ortaya çıkabilecek potansiyel sorunların önlenebilmesi için sağlık profesyonellerinin hasta öyküsü alırken bitkisel ürün kullanımlarını sorgulamaları önerilebilir.
Ülkemizde ve Dünya'da yapılan çalışmalar bitkisel destek kullanımına genellikle sağlık profesyonellerinin tavsiyesi olmaksızın başlandığını göstermektedir (12, 16, 17, 40-42). Bu çalışmada da bireylerin \%67,3'ü bitkileri komşu-tanıdığın önerisi üzerine kullandıklarını bildirmiştir. Bireylerin bitkileri doğal ve güvenilir olarak değerlendirmeleri veya sağllk çalışanlarından konuya ilişkin bilgi alamamaları, ürünlere tanıdık tavsiyesi üzerine başlamalarının nedenleri arasında olabilir. Yıldırım ve Marakoğlu'nun Konya'da yürüttüğü çalışmada diyabetli bireylerin \%98,6'sı bitkisel ürünlerin zararı olmadığını düşündüğünü belirtmiştir (17). Bu çalışmada ise hem bitkisel destek kullanan hem de kullanmayan bireylerin yaklaşık yarısı bitkilerin zararlı olabileceğini düşünmektedir. Ayrıca, bireylerin büyük çoğunluğu doktorlarından bitkilere ilişkin bilgi almak istediklerini belirtmiştir. Yıldırım ve Marakoğlu'nun çalışmasındaki bulgulara kıyasla bu çalışmaya katılan bireylerin farkındalığ 1 daha yüksek olsa da, çalışmadaki katılımcıların yarısının konuya ilişkin fikri bulunmamakta ya da bitkilerin tamamen zararsız olabileceğini düşünmektedir. $\mathrm{Bu}$ nedenle, diyabetik bireylerde konuya ilişkin farkındalık oluşturulmasının önemli olabileceği söylenebilir.

\section{SONUÇ}

Bu çalışmada, tip 2 diyabetli bireyler arasında bitkisel destek kullanımının yaygın olduğu; ürünlerin çoğunlukla sağlık çalışanlarına danışılmadan veya bilgi verilmeden kullanıldığı belirlenmiştir. Ürünlerin bilinçsiz kullanımını önlemek için sağlık çalışanlarının konuya ilişkin gerekli bilgi düzeyine sahip olmalarının, hasta öyküsü alırken bitkisel ürün kullanımını sorgulamalarının ve danışmanlık hizmeti sunabilmelerinin önemli olduğu düşünülmektedir.

\section{Finansman veya Mali Destek: Yoktur}

\section{Çıkar Çatışması: Yoktur}

Yazarların Katkısı

Çalışmanın konsepti ve dizaynı

Tasarım

Denetleme/Danışmanlık

Verilerin toplanması ve işlenmesi

Verilerin analizi ve yorumlanması

Literatür araştırması

Makalenin yazımı

Kritik gözden geçirme

: EBK : BPŞY; ZB

: EBK; BPŞY; ZB

: EBK; ZB

: EBK; BPŞY; NÖ

: EBK; BPSYY; NÖ

: EBK; BPŞY; NÖ

: EBK; BPŞY; NÖ

: ZB

Yayınlanacak versiyonun nihai onayı: EBK; BPŞY; NÖ; ZB

\section{Etik kurul:}

Hacettepe Üniversitesi Girişimsel Olmayan Klinik Araştırmalar Etik Kurulu'ndan, 13.05.2015 tarih ve GO-15/334-20 karar numarası ile alınmıştır 


\section{KAYNAKLAR}

1. International Diabetes Federation (IDF) Diabetes Atlas, 9th edition 2019 (https://www.diabetesatlas.org/en/)

2. Türkiye Endokrinoloji ve Metabolizma Derneği. Diabetes Mellitus ve Komplikasyonlarının Tanı, Tedavi ve İzlem Kilavuzu, 2019.

3. Chang HYA, Wallis M, Tiralongo E. Predictors of complementary and alternative medicine use by people with type 2 diabetes. J Adv Nurs 2012; 68: 1256-66.

4. Chang HY, Wallis M, Tiralongo E. Use of complementary and alternative medicine among people living with diabetes: literature review. J Adv Nurs 2007; 58: 307-19.

5. Cengiz Z, Budak F. Use of complementary medicine among people with diabetes in Eastern Turkey: a descriptive study. Complement Ther Clin Pract 2019; 36: 120-4.

6. Kaynak İ, Polat Ü. Diabetes mellitus'lu hastaların tamamlayıcı ve alternatif tedavileri kullanma durumları ve diyabet tutumları ile ilişkisi. Genel Tıp Dergisi 2017; 27: 56-64.

7. Patade GR, Marita AR. Metformin: A journey from countryside to the bedside. J Obes Metab Res 2014; 1: 127-30.

8. Bailey CJ. Metformin: historical overview. Diabetologia 2017; 60: 1566-76.

9. Gupta RC, Chang D, Nammi S, Bensoussan A, Bilinski $\mathrm{K}$, Roufogalis BD. Interactions between antidiabetic drugs and herbs: an overview of mechanisms of action and clinical implications. Diabetol Metab Syndr 2017; 9: 59.

10. Koyu EB. Diyabette Kullanılan Bitkisel Desteklerin Etkinliği ve Güvenilirliği. Beslenme ve Diyet Dergisi 2019; 47: 110-7.

11. World Health Organization (WHO). The use and interpretation of anthropometry: report of a World Health Organization Expert Committee, Geneva, Switzerland, 1995.

12. Karaman E, Erkin O, Senman S, Yildirim Y. The use of herbal supplements by individuals with diabetes mellitus. J Pak Med Assoc 2018; 68: 587-94.

13. Öztürk S, Gündoğdu YP, Gürsu M, Yamak M, Özkan O, Şar F, Yenigün M, Kazancioğlu R. Use of herbal products in type 2 diabetic patients. The Medical

Bulletin of Haseki 2015; 53: 214-9.

14. Pınar N, Topaloğlu M, Özsan M, Özer C, Alp H. Hatay ilinde üniversite hastanesi endokrin polikliniğine başvuran diyabet hastalarının bitkisel ürün kullanımı. Konuralp Tip Dergisi 2017; 9: 202-6.

15. Welz AN, Emberger-Klein A, Menrad K. Why people use herbal medicine: insights from a focus-group study in Germany. BMC Complement Altern Med 2018; 18: 92.

16. Azizi-Fini I, Adib-Hajbaghery M, Gharehboghlou Z. Herbal medicine use among patients with type 2 diabetes in Kashan, Iran, 2015. Eur J Integr Med 2016; 8: 570-5.
17. Yıldırım DI, Marakoğlu K. Complementary and alterna tive medicine use amongst Turkish type 2 diabetic patients: a cross-sectional study. Complement Ther Med 2018; 41: 41-6.

18. Selçuk Tosun A, Zincir H, Eliş E. Complementary and alternative medicine use and self-efficacy level in Turkish adults with type 2 diabetes mellitus. Cukurova Med J 2019; 44: 309-18.

19. Fabian E, Töscher S, Elmadfa I, Pieber TR. Use of complementary and alternative medicine supplements in patients with diabetes mellitus. Ann Nutr Metab 2011; 58: 101-8.

20. Candar A, Demirci H, Baran AK, Akpınar Y. The association between quality of life and complementary and alternative medicine use in patients with diabetes mellitus. Complement Ther Clin Pract 2018; 31: 1-6.

21. Alqathama A, Alluhiabi G, Baghdadi H, Aljahani L, Khan O, Jabal S, Makkawi S, Alhomoud F. Herbal medicine from the perspective of type II diabetic patients and physicians: what is the relationship? BMC Complement Med Ther 2020; 20: 65.

22. Deyno S, Eneyew K, Seyfe S, Tuyiringire N, Peter EL, Muluye RA, Tolo CU, Ogwang PE. Efficacy and safety of cinnamon in type 2 diabetes mellitus and pre-diabetes patients: a meta-analysis and meta-regression. Diabetes Res Clin Pract 2019; 156: 107815.

23. Ilhan M, Demir B, Yuksel S, Çataklı SA, Yıldız RS, Karaman O, Taşan E. The use of complementary medicine in patients with diabetes. North Clin Istanb 2016; 3 : 34-8.

24. Kaatabi H, Bamosa AO, Badar A, Al-Elq A, Abou-Hozaifa B, Lebda F, Al-Khadra A, Al-Almaie S. Nigella sativa improves glycemic control and ameliorates oxidative stress in patients with type 2 diabetes mellitus: placebo controlled participant blinded clinical trial. PloS One 2015; 10: e0113486.

25. Bamosa AO, Kaatabi H, Lebdaa FM, Elq AM, Al-Sul tanb A. Effect of Nigella sativa seeds on the glycemic control of patients with type 2 diabetes mellitus. Indian J Physiol Pharmacol 2010; 54: 344-54.

26. Bilal A, Masud T, Uppal AM, Naveed AK. Effects of Nigella sativa oil on some blood parameters in type 2 diabetes mellitus patients. Asian Journal of Chemistry. 2009; 21: 5373-81.

27. El-Shamy KA, Mosa MMA, El-Nabarawy SK, El-Qat $\tan$ GM. Effect of Nigella sativa tea in type 2-diabetic patients as regards glucose homeostasis, liver and kidney functions. J Appl Sci Res 2011; 7: 2524-34.

28. Arslan E, Sayin S, Demirbas S, Cakar M, Somak NG, Yesilkaya S, Sağlam K. A case study report of acute renal failure associated with Nigella sativa in a diabetic patient. J Integr Med 2013; 11: 64-6.

29. Bamosa A. Nigella sativa is a safe herbal product. J Integr Med 2014; 12: 66.

30. Abunab H, Dator WL, Hawamdeh S. Effect of olive leaf extract on glucose levels in diabetes-induced rats: a systematic review and meta-analysis. J Diabetes 2017; 9: 


\section{7-57}

31. Cam ME, Hazar-Yavuz AN, Yildiz S, Ertas B, Ayaz Adakul B, Taskin T, Alan S, Kabasakal L. The methanolic extract of Thymus praecox subsp. skorpilii var. skorpilii restores glucose homeostasis, ameliorates insulin resistance and improves pancreatic $\beta$-cell function on streptozotocin/nicotinamide-induced type 2 diabetic rats. J Ethnopharmacol 2019; 231: 29-38.

32. Soliman MM, Nassan MA, Ismail TA. Origanum majo ranum extract modulates gene expression, hepatic and renal changes in a rat model of type 2 diabetes. Iran $\mathrm{J}$ Pharm Res Suppl 2016; 15: 45-54.

33. Araki R, Fujie K, Yuine N, Watabe Y, Nakata Y, Suzuki $\mathrm{H}$, Isoda H, Hashimoto K. Olive leaf tea is beneficial for lipid metabolism in adults with prediabetes: an exploratory randomized controlled trial. Nutr Res 2019; 67: 60-6.

34. de Bock M, Derraik JGB, Brennan CM, Biggs JB, Morgan PE, Hodgkinson SC, Hofman PL, Cutfield WS. Olive (Olea europaea L.) leaf polyphenols improve insulin sensitivity in middle-aged overweight men: a randomized, placebo-controlled, crossover trial. PloS One 2013; 8: e57622.

35. Florentin M, Liberopoulos E, Elisaf MS, Tsimihodimos V. No effect of fenugreek, bergamot and olive leaf extract on glucose homeostasis in patients with prediabetes: a randomized double-blind placebo-controlled study. Arch Med Sci Atheroscler Dis 2019; 4: 162-66.

36. Bozdemir Ç. Türkiye'de yetişen kekik türleri, ekonomik önemi ve kullanım alanları. Yüzüncü Y1l Üniversitesi Tarım Bilimleri Dergisi 2019; 29: 583-94.
37. Soner BC, Sahin AS, Sahin TK. A survey of Turkish hospital patients' use of herbal medicine. Eur J Integr Med 2013; 5: 547-52.

38. Martins RR, Duarte Farias A, Russel Martins R, Gouveia Oliveira A. Influence of the use of medicinal plants in medication adherence in elderly people. Int J Clin Pract 2016; 70: 254-60.

39. Ezuruike U, Prieto JM. Assessment of potential herb-drug interactions among Nigerian adults with type-2 diabetes. Front Pharmacol 2016; 7: 248.

40. Amaeze OU, Aderemi-Williams RI, Ayo-Vaughan MA, Ogundemuren DA, Ogunmola DS, Anyika EN. Herbal medicine use among type 2 diabetes mellitus patients in Nigeria: understanding the magnitude and predictors of use. Int J Clin Pharm 2018; 40: 580-8.

41. Kamel FO, Magadmi RM, Hagras MM, Magadmi B, AlAhmad RA. Knowledge, attitude, and beliefs toward traditional herbal medicine use among diabetics in Jeddah Saudi Arabia. Complement Ther Clin Pract 2017; 29: 207-12.

42. Vickers KA, Jolly KB, Greenfield SM. Herbal medicine: women's views, knowledge and interaction with doctors: a qualitative study. BMC Complement Altern Med 2006; 6: 40 . 